необхідних і достатніх способів дій). Отримані експериментальні дані дали можливість уперше визначити та схарактеризувати типи професійної спостережливості майбутніх вихователів дошкільних навчальних закладів (проникливий, нормативний, потенційний та поверховий). Встановлено, що у студентів домінує потенційний тип, який проявляється у їхньому прагненні та можливості помічати індивідуальні особливості дітей (батьків, колег). Але майбутніх педагоги при цьому допускають помилки в процесі інтерпретації цих проявів. Це зумовлено недостатньою сформованістю здатності до визначення необхідних і достатніх розпізнавальних зовнішніх проявів особистості, їх диференціації, порівняння та інтерпретації. Ці особливості прояву професійної спостережливості майбутніх фахівців вказують на необхідність і можливість ії цілеспрямованого розвитку на етапі фахової підготовки.

Ключові слова: професійна спостережливість (прониклива, нормативна, потенційна, поверхова), професійно важлива якість, вихователь дошкільних навчальних закладів.

Submitted on 18.05.2017

Reviewed by Doctor of Psychology, prof. V. Kuzmenko

UDC: $37.015 .3+159.922$

DOI: https://doi.org/10.24195/2414-4665-2017-7-4

Oleksii Chebykin, Doctor of Psychology, professor, head of the Department of Theory and Methods of Practical Psychology, Olena Kosianova, PhD (Candidate of psychological Sciences), lecturer of the Department of Theory and Methods of Practical Psychology, South Ukrainian National Pedagogical University named after K. D. Ushynsky, 26, Staroportofrankivska Str., Odessa, Ukraine

\title{
DECEITFULNESS ACCORDING TO THE INDICATORS OF EMOTIONAL MATURITY METHODOLOGY AND POLYGRAPH EXAMINATION
}

There has been developed a theoretical model of the polygraph research which consists of three groups of categories and concepts used in the organization, obtaining results and data interpretation: physiological characterizing the logics of these processes; psychological reflecting essential properties and relationships; instrumental-technical describing the polygraph method specificity. There has been created the polygraph questionnaire aimed at diagnosing deceitfulness that allows to identify and analyze indicators characterizing predisposition to verbal, concealed and general deception. The surveyed sample have been grouped according to: gender (men, women); areas of specialists' training (psychology, history, physics, navigation, fine art); the degree of deceitfulness (high, medium, low); the type of emotional maturity (empathic, self-regulating, expressive, expressive-empathic). Summarizing the correlation analysis data concerning the general sample, it has been found that the integrative parameter of deceitfulness has the greatest number of correlations and is rather closely related to the indicators determining emotional maturity and its components: emotional expressiveness, emotional self-regulation and empathy. The intergroup factor analysis in the groups with different levels of predisposition to general deception has proved that, depending on the level of deceitfulness, there are changes in the dominance of any given components of emotional maturity. A thorough analysis has shown that there are significant interrelations between the indicators of deceitfulness and emotional maturity in the structure of the empathic type that may indicate high probabilistic deceitfulness. In general, the obtained results confirm our hypothesis stating that personality deceitfulness can be determined by the characteristics of emotional maturity, the main of which is the empathic constituent (according to the results of our study).

Keywords: polygraph examination, types of emotional maturity, deceitfulness, diagnostics of personality deceitfulness based on the data of emotional maturity

\section{Introduction}

An active implementation of the polygraph method into psychological practice is sufficiently relevant nowadays due to the increasing requirements for moral and ethical peculiarities of the individual in different life circumstances. In this aspect, the role and functions of the data obtained using the polygraph take one of the leading places in both theoretical and applied psychological works [1, 17, 41, 43 and others]. At the same time, completely pragmatic tasks are being set and solved: disclosure of various types of crimes, security in enterprises, personnel and official inspections, reduction of personnel 
turnover, industrial injuries and professional diseases, improvement of work quality and efficiency, determination of professional abilities or bad habits, decrease in expenses and time spent on professional training and more.

Scientific works show that studying the peculiarities of physiological function changes in the process of polygraph researches allows to predict people's behaviour in extreme situations, preventing nervous breakdowns in professional activities and providing timely correction of workers' psychological state, in particular, it applies to the representatives of dangerous jobs: employees of special services, security agents, aviation and railway transport workers and others.

The generalization of various works and publications proves that the issue of the polygraph method use, despite the convincing data obtained, is controversial in the professional environment. On the one hand, it is most clearly observed in different theoretical approaches to the explanation of testing results according to this methodology $[14,15,25,26,32,33,35$ and others $]$. On the other hand, there are some differences regarding the construction of the testing procedure itself, development of the appropriate diagnostic material and requirements to it, peculiarities of the selection procedure, processing and interpretation of the obtained indicators according to their validity and system representation [1, 21, 22, 23, 26 and others]. It is impossible to ignore the problem concerning the complexity of the polygraph testing implementation, as well as the comparison of its results with the results of other methods aimed at diagnosing deceitfulness [3, 12, 43, 47, 48 and others].

It should be noted that most diagnosed characteristics of the polygraph method are based on the indicators that can characterize the features of the emotional sphere of the individual directly or indirectly. The latter issue was studied mainly in the works of foreign researchers $[33,35,38,40,44,45$ and others], which is due to the earlier introduction of polygraph techniques into different fields of their possible use. Summarizing these and other works, it should be mentioned that scholars have attempted to identify personal characteristics that may affect deceitfulness, i.e.: gender (B. De Paulo, J.A. Epstein, D.A. Kashy, S.E. Kirkendol, H.T. Reis, C. Saarni, M. Senchak, B. Solomon, M.M. Wyer and others), age (J. Lewis), personality traits (B. De Paulo, D.W. Gerbing, J.E. Hunter, D.A. Kashy, G.A. Miller, A. Vrij, L. Wilson and others), emotions (P. Ekman, I. Leslie, S. Walters, O. Freight and others), etc. It is noteworthy that there are such domestic researches (O.T. Baryshpolets, Ye.V. Zadniprianets, N.M. Mayorchak, S. Malievych, I.A. Trukhin, I.O. Filenko and others) that deal mainly with the issue of determining the moral and social aspects of deception. The absence of special studies concerning the role of the emotional sphere in the manifestation of deception complicates the process of its cognition. This is especially appropriate for emotional maturity of an individual.
Based on the mentioned above, the present study devoted to the interrelationship between emotional maturity and manifestation of students' deceitfulness gives the opportunity to penetrate more deeply into the sphere of moral ideas and requirements of modern youth and thereby expand our knowledge about psychological peculiarities of this age period. It can be assumed that the definition and disclosure of the emotional maturity role or its certain features in the determination of youth's deception will significantly broaden the existing understanding of the deceitfulness diagnostics peculiarities in the aspect of this procedure optimization. After all, the juvenile age is a deciding period in the formation of personality features associated with the emotional sphere development (O. Chebykin, I. Pavlova).

The results of these and other studies also describe certain theoretical and methodological ideas that can be used in the analysis of the relationship between personality deceitfulness (using the polygraph method) and the data on the development of the emotional sphere components.

The aim of the study is to ground theoretically and investigate the interrelationship of deceitfulness in individuals with different types of emotional maturity empirically.

To achieve this goal, the following tasks were set:

1) to generalize basic historical preconditions, as well as theoretical and methodological ideas concerning the use of the polygraph method in psychological science and practice.

2) to define the role of the emotional sphere in the content of the polygraph method indicators.

3 ) to reveal and describe the leading components and types of emotional maturity of an individual, as well as their research procedures.

4) to determine the interrelationship between the types of emotional maturity and the deceitfulness data.

Due to the aim and tasks of the study the following research methods were used: theoretical (analysis of domestic and foreign scientific sources, generalization of concepts and approaches the polygraph method is based on, and the role of the emotional sphere in determining deceitfulness of the individual); empirical (questionnaires, observations, oral interviews, conversations); instrumental (polygraph method); methods of statistical data processing (determination of statistically reliable indicators according to Student's t-criterion, correlation analysis, factor analysis, dispersion analysis - SPSS 13.0 for Windows was used for this purpose)

A diagnostic complex consisted of both generally recognized methods and a specially designed polygraph questionnaire. Studying the emotional sphere, "Emotional maturity diagnostics" questionnaire (O. Chebykin) was used [27]. To determine the specificity and nature of personality deceitfulness, the polygraph questionnaire based on the adapted variant of the "Marston Deception Test" (Relevant/Irrelevant Test - R/I test by W. Marston ) [12] was also used according to the purpose of our study. 
379 students from different universities (ranging in age from 18 to 23 ) were involved in the empirical research.

\section{Discussion}

Solving the first task, we have summarized a large number of data that allowed us to distinguish three stages in the history of the polygraph method development: the first stage (the ancient history of mankind) - a search for personality characteristics which can characterize certain predispositions to deception; the second stage (the beginning of the $18^{\text {th }}$ century - the end of the $19^{\text {th }}$ century) creation of separate methods aimed at detecting deception; the third stage (the beginning of the $20^{\text {th }}$ century nowadays) - creation and implementation of the complex instrumental polygraph methodology. The polygraph devices have been systematised, proceeding from three principles: the element basis or data fixation procedure (analogue, digital, manual); the complexity of configuration (basic, extended, combined); the way of measuring or sensor fixation (contact, contactless and combined).

It has been proved that the polygraph remains the most effective means of detecting concealed information among all existing methods. However, it has been found out that nowadays there are many different tools of detecting concealed information (micro-gesture and microexpression analysis; magnetic resonance imaging (MRI); the electroencephalographic method; the graphological method; the eye movement trajectory analysis; tests examining the voice with the help of stress analysers; the use of computer programs on brain activity (MindReader, SprintTest); thermal imaging analysis, etc.), presented by various sophisticated and sensitive devices that can be used to determine whether a person is lying or telling the truth. Many of them are more acceptable as an additional channel to the polygraph, and only some of them deserve some attention as an alternative to it. As for the use of the polygraph method, it enables to measure, record and show the dynamics of changes in the vegetative and brain activity of the subject while being given the stimulus. At the same time, after having passed through many historic periods, the polygraph method is still in the stage of improvement both of the devices themselves and theoretical and methodological grounds of the validity and reliability of the data obtained through it.

Clarifying the categorical apparatus used in the polygraph study, it has been ascertained that "deception" is an integrated category which includes "lie" and "nontruth". To prove this statement, it is noted that "deception" can be expressed through: speech messages; actions or their absence (deceptive manoeuvre, machinations, play, roles, hypocrisy, breaking promises); the purpose based on attitudes, values, motives and intentions of the subject and can be expressed with a hostile orientation (lie) or without it (non-truth, nonsense, fables); an object manifesting itself in inaccurate or true information presented in such a way that the interlocutor makes conclusions which contradict the exceptional state of things; a subject's action pursuing certain interests; the process of introducing inaccurate information; a result or action that has reached its goal, i.e. interlocutors accept untrue information as true and are guided by it in their follow-up, that means they are deceived $[2,6,7,9,11,14$ and others].

There has been presented a theoretical model of the polygraph research structure, which consists of three groups of categories and concepts used in the organization, obtaining results and data interpretation: physiological characterizing the logic of these processes; psychological reflecting essential properties and relationships; instrumental-technical describing the polygraph method specificity. The role and principles of major physiological sensors recorded by the polygraph have also been clarified: breathing (top, bottom), galvanic skin response, blood pressure, photoplethysmogram, tremor (motor activity sensor). There has been examined the relationship between physiological reactions and human emotional experiences (and other mental processes) allowing to record vegetative changes using the polygraph as an objective and effective method diagnosing the fact of hiding some information.

Based on the analysis of scientific literature $[3,12$, $15,17,21,22,23,26$ and others], two groups of polygraph theories have been distinguished and described. Thus, the first group, defined as "cognitive polygraph theories" (the key factors of physiological changes in the polygraph examination are cognitive mental processes) includes: "theory of focused memory testing" (Yu. Holodnyi), "attention theory", "conflict theory" (G.H. Borland, D.C. Raskin), "dichotomization theory" (G. Ben-Shakhar, I. Lieblich), "orientation theory" (M. Kleiner). The second group, identified as "emotional and volitional polygraph theories" (the key factors of physiological changes in the polygraph examination are emotional and volitional mental processes, manifested as emotions, feelings, aberrations, motive struggle, decisionmaking or goal setting) consists of "two-factor theory of emotions" (S. Schachter, J. Singer), "information theory" (P.V. Simonov), "conditioned reflex theory" (I.P. Pavlov), "threat-of-punishment theory" (A. Mosso), "motivational theory of functional systems" (V.A. Varlamov). Consequently, our thorough analysis of the existing theories can be a theoretical platform for the creation of a coherent conceptual model of the polygraph method theoretical basis.

Summarizing theoretical data, a classification of polygraph tests has been proposed. Thus, the first group, selected according to "types of questions", includes: tests of probation and neutral questions and their combinations relating to the methodology of probation and neutral questions; tests of control questions relating to the methodology of control questions; "Peak Strain" Test, "Peak Strain" Test of the Known Solution, "Peak Strain Search" Test, Guilty Knowledge Test, Guilty Knowledge Searching Test, Event Knowledge Test and others which can be assigned to the methodology of detecting concealed information. According to other classifications, the follow- 
ing tests can be marked out: verification and service; direct and indirect; strain peak tests and benchmark tests; single-tasking and multi-tasking.

It has been discovered that various features of the emotional sphere can serve as essential signs of deception - it is proved by a large number of indirect studies devoted to the content of the indicators used in the polygraph study [1, 12, 14, 25 and others]. It is clearly observed in the analysis of emotional states [5, 10, 24, 30 and others] and data in which this inclination is connected with emotional lability, resistance, empathy, etc.

Solving the second task, there have been outlined major theoretical and methodological approaches, the development of the individual emotional maturity content is based on; there have been generalized a general understanding of emotional maturity; there have been examined the main structural components of emotional maturity in general, as well as at the personal and interpersonal levels of manifestation; there has been described a typological model of individual variants of the emotional maturity formation and development; it has been shown that the typology mentioned above can serve as the basis for searching both individual indicators and their complex giving opportunity to judge about personality deceitfulness.

Summarizing scientific data $[10,13,24,27,30,32$ and others], two main theoretical and methodological approaches, the development of the individual emotional maturity content is based on, have been featured and proved. First, some scientists tend to distinguish "assimilation" models of emotional maturity as: a resumptive emotional and intellectual construct that reflects emotional maturity (H.V. Yusupova); the identification of emotional maturity with emotional competence as the ability to act according to the internal environment of one's own feelings and desires (R. Busk); knowledge about oneself and the ability to be the master of one's own emotions (D.H. Heath, C. Lambert); emotional maturity is considered in connection with emotional literacy (O.L. Yakovleva, D. Goleman); emotional maturity as a new formation of a certain age, i.e. a characteristic of various emotional manifestations associated with a certain age period (D.N. Isayev, N.Yu. Maksymova, J. Murray and others); emotional maturity as a social norm - one of the characteristics peculiar to an adult, i.e. a biologically mature man who internalizes and follows norms and values of culture or society in which they live (A.N. Luk, A. Reber, P. Fraisse and others); emotional maturity as emotional intelligence (D. Caruso, R.K. Cooper, H. Gardner, J.D. Mayer, P.Salovey, A.Sawaf and others); an aspect of the child's readiness for school manifesting itself in impulsivity decrease, ability to obey orders, follow instructions, communicate and co-operate with peers, etc. (A. Maurer). Second, "generative" models of emotional maturity can be presented as: emotionally mature personality is "a fully functioning person", who is open to understanding and trusting their own feelings; able to experience emotions of different range, depth and intensity; can verbalize; capable of empathy (K. Rogers); is sensitive to their emotions and understands them (O.S. Kocharian), open to emotional experience and aware of their own feelings (O.O. Chudina); emotionally mature personality is a self-actualizing person, i.e. responsible for their actions and emotions, living in the present, moment, being spontaneous and creative (A. Maslow); emotionally mature personality is an authentic person who is able: to diverge from socio-normalized and socio-controlled feelings for real: to see and feel the entire spectrum of real emotions "here and now"; to become free and responsible for their own emotions, feelings, experiences, life; to decline stereotypes and clichés; to become open to a new experience (A. Meneghetti, F. Perls and others); emotionally mature personality is like a child characterized by spontaneity, emotionality, childish frankness and liveliness of feelings, as well as real experiencing life and himself-herself in it (A. Lawen, V. Reich); emotionally mature person is like an adult possessing such qualities as: developed mind (Freud et al.), maturity of defence mechanisms (A. Freud et al.), positive "sense of self" (H. Kohut and others.), satisfaction with object relations (M. Klein et al.); emotionally mature personality included in the transpersonal structures, identifying their own maturity and mental health (S. Grof), revealing the divine origin of a human (A. Mindell); emotionally mature personality characterized by a high degree of the emotional sphere development at the level of emotional response adequacy in certain socio-cultural conditions (I.G. Pavlova, O.Ya. Chebykin).

Solving the third task, there has been generalized the understanding of emotionally mature personality and proved that emotionally mature people have a full control over their life and a high level of success, including a high level of life and happiness, self-confidence, success in relationships, etc. At the same time, there has been shown that a low level of emotional maturity is characterized by the absence or bad formation of emotional reactions to the surrounding world. An understanding of the essence, content and structure of emotional maturity as an integrative personal quality characterizing the degree of the emotional sphere development at the level of emotional response adequacy in certain socio-cultural conditions has been established. The main structural components of the individual emotional maturity in general, as well as at the personal and interpersonal levels of manifestation have been considered. They are emotional self-regulation (intro-self-regulation and extra-self-regulation), empathy (intro-empathy and extra-empathy), emotional expressiveness (intro-expressiveness and extra-expressiveness). Thus, each of the emotional maturity components, integrating with other features, qualities and processes, is reflected both at the conscious and subconscious levels of the human psyche. For emotional maturity is understood as a degree of the emotional sphere development, it is important to distinguish how such a development is interconnected with various aspects of personality traits and, in particular, deceitfulness. 
Taking into account O. Ya. Chebykin and I. G. Pavlova's studies, there has been developed a typological model of individual variants of the emotional maturity formation and development which includes 7 types: expressive, self-regulating, empathic, harmonic, selfregulating-empathic, expressive-empathic, and expressive-self-regulating. Consideration of the above typology serves as the basis for searching the relationship between individual peculiarities, as well as between a general level of emotional maturity and deceitfulness.

Based on the purpose and sequence of task solving, stages of the empirical research have been formed: preparation, diagnostics (including a diagnostic-instrumental stage - polygraph examinations), processing and interpretation of the data.

At the first, preparatory, stage there has been created a set of psychodiagnostic research procedures, aimed at the construction of a polygraph questionnaire in accordance with the aim of the study. For this purpose, a preliminary analysis of socio-moral ideals and human values has been made in order to create the polygraph questionnaire on their basis. Consequently, the polygraph questionnaire, being developed to reach the goal of our study, consists of six groups of tests (topics), each of which corresponds to the direction of value (going to school; studying in a higher educational institution; employment and material values; health; family; friends and communication) plus an additional "lie test" which is necessary for the polygram analysis procedure and obtaining results. In general, the polygraph questionnaire includes 87 questions, 51 of which ("significant" questions) are aimed at detecting deception in basic spheres of human values.

The second stage is diagnostic. At this stage, students have been examined using the indicated methods (mainly in the first half of the day). It should be noted that the ground of this stage - both according to the organization of the study and the duration and requirements for the procedure - is directly a polygraph test, which is represented in our work by the sequence of phases. As a result of the research, we have identified the indicators diagnosed by the polygraph methodology: predisposition to verbal deception, i.e. the subject confession in the past deception; predisposition to concealed deception discovered by the expert analysis of the received polygrams; general deception which is a combination of levels of predisposition to verbal and concealed deception.

At the third stage of our study, statistical data processing has been performed (determination of correlation relationships of the diagnosed indicators), the results of the study have been generalized in order to reveal interdependencies in the groups between indicators of the deceitfulness level and indicators of the emotional sphere, as well as the received data have been described and interpreted.

Noting the received primary data on the indicators of deceitfulness and emotional maturity of the general sample, it has been found out that the greatest variability is observed in the indicators characterizing predisposition to verbal deception $(\sigma=7.51 ; \mathrm{CV}=40.6)$ and the deception detected with the help of polygraph $(\sigma=7,38 ; C V=51.9)$, as well as general $(\sigma=7.37$; $\mathrm{CV}=22.5)$. An integral index of emotional maturity also has a high variability $(\sigma$ $=5.21 ; \mathrm{CV}=22.5)$. A further correlation analysis of the general sample shows that an integrative parameter of deceitfulness has the greatest number of connections and is rather closely $(\mathrm{p}<0.01)$ related to the indicators determining emotional maturity $(r=0.644)$ and its components: emotional expressiveness $(\mathrm{r}=0.647)$, emotional selfregulation $(\mathrm{r}=0.363)$ and empathy $(\mathrm{r}=0.489)$.

Solving the fourth task, we have grouped the surveyed sample of subjects according to: gender (men, women); areas of specialists' training (psychology, history, physics, navigation, fine art); the degree of deceitfulness (high, medium, low); the type of emotional maturity (empathic, self-regulating, expressive, expressiveempathic). The results obtained relating to the above groups have proved the following.

First, the analysis of differences in the levels of the emotional maturity and deceitfulness indicators in males and females has indicated that in some cases there are differences, but mostly - only at the significance level of trends. Such results may reflect a certain degree of independence in the manifestation levels of the emotional maturity and deceitfulness indicators among the representatives of different genders, based on the surveyed sample.

Secondly, in the groups formed according to the direction of specialization (psychology, history, physics, navigation, fine art) there are statistically significant differences in the following indicators: predisposition to verbal and concealed deception. It should be noted that the main statistically significant differences in the above indicators are observed in the group of "psychologists" which, to some extent, may indicate that the members of this group are more likely to deceive. In order to determine the leading features, the dispersion intergroup analysis has been made (in groups: history, psychology, physics, navigation, fine art), allowing to identify the indicators that serve as influential (independent variables). The latter include those that characterize verbal $(\mathrm{F}=2.605)$ and concealed $(\mathrm{F}=3.538)$ deception.

Third, there are significant differences in the manifestation of emotional maturity and its components at the level of the deceitfulness integral index. In this aspect, as mentioned above, we have featured three groups of the respondents according to the degree of deceitfulness (high, medium, low), using two ways. The first one is determining the boundaries of the average level of the deceitfulness general index by calculating the average arithmetic mean. The second way is based on the research results (L.F. Burlachuk, S.M. Morozov) stating that in the normal distribution $68 \%$ of measurements of any psychological phenomenon belong to the average level. As shown above, the following should be taken: the low level of deceitfulness is $0-25$ points, the medium level is $26-40$ points, and the high level is $41-51$ points according to the 
created polygraph questionnaire. Further intergroup factor analysis in the groups with different levels of predisposition to general deception has proved that, depending on the level of deceitfulness, there are changes in the dominance of any given component of emotional maturity. Thus, the predominance of emotional self-regulation in the structure of the investigated indicators and its restraining role in the formation and manifestation of general deception is observed in the group with the "high" level of deceitfulness. In the group with the "middle" level of deceitfulness, there is a domination of emotional empathy, and in the group with the "low" level of general deception, - a set of indicators of self-regulation, deceitfulness and empathy. The obtained results have revealed the interrelationship between the development of the emotional maturity components and deceitfulness.

Fourth, there is the relationship between the development of the emotional maturity components and deceitfulness. To test this hypothesis, we have chosen the correlation analysis based on the types of emotional maturity determined in this sample (expressive, self-regulating, empathic, expressive-empathic). Then, considering the results of the correlation analysis in the structure of the empathic type, significant interrelations between the deceitfulness and emotional maturity indicators are observed. Summarizing the data, we can state that the empathic type has high probabilistic deceitfulness. To some extent, these results confirm our hypothesis and serve as the ground for using pre-evaluation of the empathic type in the deceitfulness diagnostics. So, if it is necessary to reveal deception with the help of polygraph or other techniques, it is preferable to check the representatives of the empathic type first of all. The peculiarities of correlation relations between the emotional maturity and deceitfulness indicators in the structure of the expressive and selfregulating types can also indicate their representatives' deceitfulness in a certain way. It has been established that the representatives of the expressive-empathic type of emotional maturity do not have structural interrelations between the indicators of predisposition to verbal and concealed deception and the emotional maturity data. That is why it is possible to note that there is no relationship between the predisposition to concealed and verbal deception and the emotional maturity data among the representatives of this type, in contrast to the representatives of the empathic, expressive and self-regulating types.

\section{Conclusions}

Taking into account all of the foregoing arguments, the following conclusions can be made.

1. It has been found out that the issue of deception evaluation has a long history, and scientists have been interested in methods of its evaluation for a long time. There have been distinguished three stages in the polygraph method development: the stage of search for personality characteristics which can characterize predispositions to deception; the stage of creation of certain methods aimed at detecting deception; the stage of creation and implementation of the complex instrumental polygraph methodology.

There has been developed a theoretical model of the polygraph research which consists of three groups of categories and concepts used in the organization, obtaining results and data interpretation: physiological characterizing the logic of these processes; psychological reflecting essential properties and relationships; instrumental-technical describing the polygraph method specificity.

Based on the analysis of the existing approaches, two groups of polygraph theories have been presented in the study. They are "cognitive polygraph theories" ("theory of focused memory testing", "attention theory", "conflict theory", "dichotomization theory", "orientation theory") and "emotional and volitional polygraph theories" ("twofactor theory of emotions", "information theory", "conditioned reflex theory", "threat-of-punishment theory", "motivational theory of functional systems").

2. It has been proved that most indicators of the polygraph methodology reflect different features of emotional maturity directly or indirectly. There have been outlined major theoretical and methodological approaches, the development of the emotional maturity content is based on. First, there are "assimilation" models presented by identification of emotional maturity with emotional competence, emotional literacy, a new formation of a certain age, a social norm, emotional intelligence, etc. Second, there are "generative" models characterizing emotionally mature personality as: "a fully functioning person"; a self-actualizing person; an authentic person; a child; an adult; included in the transpersonal structures; having a high degree of the emotional sphere development at the level of emotional response adequacy in certain socio-cultural conditions.

3. There has been described a typological model of individual variants of the emotional maturity formation and development which includes 7 types (expressive, selfregulating, empathic, harmonic, self-regulating-empathic, expressive-empathic and expressive-self-regulating) as probabilistic determinants of personality deceitfulness.

4. The polygraph questionnaire aimed at diagnosing deceitfulness has been created. It allows to distinguish and analyze the indicators characterizing predisposition to verbal, concealed and general deception.

Summarizing the correlation analysis data concerning the general sample, it has been established that the integrative parameter of deceitfulness has the greatest number of connections and is rather closely related to the indicators determining emotional maturity and its components: emotional expressiveness, emotional selfregulation and empathy.

The intergroup factor analysis in the groups with different levels of predisposition to general deception has proved that, depending on the level of deceitfulness, there are changes in the dominance of any given component of emotional maturity. Thus, the predominance of emotional self-regulation in the structure of the investigated indicators and its restraining role in the formation and manifes- 
tation of general deception is observed in the group with the "high" level of deceitfulness. In the group with the "middle" level of deceitfulness, there is a domination of emotional empathy, and in the group with the "low" level of general deception, - a set of indicators of selfregulation, deceitfulness and empathy.

A thorough analysis has shown that there are significant interrelations between the deceitfulness and emotional maturity indicators in the structure of the empathic type that may indicate high probabilistic deceitfulness. The peculiarities of correlation relations between the emotional maturity and deceitfulness indicators in the structure of

\section{REFERENCES}

1. Alekseyev, L. (2011). Psikhofiziologiya detektsii lzhi: Metodologiya [Psychophysiology of lie detection: Methodology]. Moscow: OOO "Galleya-print" [in Russian].

2. Baryshpolets, O. T. (2013). Brekhnya $v$ informatsiynomu prostori ta mizhosoboviy komunikatsiyi: monohrafiya [Lying in the information space and interpersonal communication: a monograph]. Kirovohrad: Imeks-LTD [in Ukrainian].

3. Varlamov, V. A. (2004). Detektor lzhi [Lie detector]. Krasnodar [in Russian].

4. Vihman, A.A. (2010). Nekotoryye osobennosti individualnosti lzhetsov yunosheskogo vozrasta [Some peculiarities of adolescent liars' personality] Sibirskiy pedagogicheskiy zhurnal - Syberian Pedagogical Journal [in Russian].

5. Helgorn, E. \& Loufborrow, G. (1966). Emotsii emotsionalnyye rasstroystva. Neyrofiziologicheskoye issledovaniye [Emotions and emotional disorders. Neurophysiological research]. Moscow: Mir [in Russian].

6. Dubrovskiy, D.I. (2010). Obman. Filosofskopsikhologicheskiy analiz [Deception. Philosophicalpsychological analysis]. 2nd ed. rev. Moscow: Kanon + ROOI "Reabilitatsiya" [in Russian].

7. Zhdanova, O.O. (1998). Psikhologicheskiye osobennosti ponimaniya lzhi. Tekst [Psychological features of understanding the lie. Text]. Vestnik Rossiyskogo gumanitarnogo nauchnogo fonda - Bulletin of Russian Humanitarian Scientific Foundation, 4, 183-189 [in Russian].

8. Zhurin, S. I. \& Aliushin, M. V. (2003). Obzor sovremennykh poligrafov [Overview of modern polygraphs]. Mir i bezopasnost - Peace and safety, 2 [in Russian].

9. Znakov, V. V. (1999). Zapadnyye $i$ russkiye traditsii $v$ ponimanii lzhi: razmyshleniya russkogo psikhologa nad issledovaniyami Polya Ekmana [Western and Russian traditions in understanding the lie: Russian psychologist's reflections on Paul Ekman's studies]. Saint-Petersburg: Piter [in Russian].

10. Izard, K. Ye. (2000). Psikhologiya emotsiy [Psychology of emotions]. Saint-Petersburg: Piter [in Russian]. the expressive and self-regulating types demonstrate the mentioned tendency to a lesser extent. In general, the obtained results confirm our hypothesis stating that personality deceitfulness can be determined by the characteristics of emotional maturity the main of which is the empathic constituent (according to the results of our study). Further research work is supposed to be aimed at organizing and conducting experiments in the context of the topic "Psychology of deception in interpersonal interactions" and developing a scientific platform of Ukrainian polygraphology.

11. Ilyin, Ye.P. (2013). Psikhologiya obshcheniya $i$ mezhlichnostnyh otnosheniy [Psychology of communication and interpersonal relations]. SaintPetersburg: Piter [in Russian].

12. Kniazev, V. \& Varlamov, G. (2012). Poligraf $i$ yego prakticheskoye primeneniye: ucheb. posobiye [Polygraph and its practical application: Textbook]. Moscow: "Print-Tsentr" [in Russian].

13. Kocharian, O. S. \& Piven, M. A. (2012). Emotsiyna zrilist osobystosti: doslidzhennya fenomenu [Personality emotional maturity: the phenomenon study]. Naukovyi visnyk Mykolayivskoho derzhavnoho universytetu imeni V.O.Sukhomlynskoho: zbirnyk naukovyh prats Scientific Bulletin of Mykolayiv State University named after Sukhomlynskyi: collection of scientific works, 9, (Vol. 2), 140-144 [in Ukrainian].

14. Lesli, I. (2012). Prirozhdennyye lzhetsy. My ne mozhem zhit bez obmana [Inborn liars. We can not live without deception]. Moscow: Ripol Klassik [in Russian].

15. Luriya, A.R. (2002). Priroda chelovecheskih konfliktov: Obyektivnoye izucheniye dezorganizatsii povedeniya cheloveka [The nature of human conflicts: An objective study of human behaviour disorganization]. Moscow: "Kogito-Tsentr" [in Russian].

16. Maksymenko, S.D. (2007). Psykholohiia osobystosti: pidruchnyk [Personality psychology: textbook]. Kyiv: TOV “KMM" [in Ukrainian].

17. Motliah, O.I. (2012). Polihraf: naukova pryroda pohodzhennia, normatyvno-pravove rehuliuvannia ta dopustymi mezhi zastosuvannia: monohrafiia [Polygraph: scientific nature of origin, normative-legal regulation and permissible limits of implementaion: monograph]. Kyiv: Osvita Ukrayiny [in Ukrainian].

18. Nikitina, Ye. V. (2008). Lozh i obman: problema ponyatiynogo razgranicheniya [Lying and deception: the problem of conceptual delineation]. Psikhologicheskoye obespecheniye natsionalnyh proektov razvitiya obshchestva: opyt, innovatsionnyye tekhnologiyi, mentalnyye baryery: materialy mezhduradnogo kongressa - Psychological support of national projects of society development: experience, innovative technologies, mental barriers: materials of the international congress (pp. 275277). Moscow; Kostroma: KGU im. N.A. Nekrasova [in Russian]. 
19. Nikititna, Ye. V. (2002). Teoreticheskiye aspekty fenomena lzhi [Theoretical aspects of the phenomenon of lying]. Sotsialnaya psikholohiya XXI stoletiya - Social psychology of 21st century (pp. 274-276). Yaroslavl, [in Russian].

20. Orlov, Yu. K. \& Holodnyi Yu. I. (2009). Sudebno-psikhofiziologicheskaya ekspertiza s primeneniyem poligrafa: problema dopustimosti [Forensic psycho-physiological expertise using a polygraph: the problem of admissibility]. Vestnik Akademii ekonomicheskoy bezopasnosti MVD Rossii - Bulletin of Academy of Economic Security of the Ministry of Internal Affairs of Russia, 12, 83-88 [in Russian].

21. Pavlov, I.P. (2001). Refleks svobody [Freedom reflex]. Saint-Petersburg: Piter [in Russian].

22. Pelenitsyn, A.B., Soshnikov, A.P. \& Zhbankova, O.V. (2011). Tak chto zhe vsyo-taki opredeliayet poligraf? [So what does the polygraph determine?]. Vestnik kriminalistiki - Bulletin of Forensic Science, 2(3), 7-18 [in Russian].

23. Popovichev, S.V. (2011). Legko solgat tyazhelo. Instrumentalnaya detektsiya lzhi: ot ideologii $k$ tekhnologii [It's difficult to lie easily. Instrumental detection of lie: from ideology to technology]. Moscow [in Russian].

24. Simonov, P.V. (1981). Emotsionalnyi mozg [Emotional brain]. Moscow: Nauka [in Russian].

25. Fry, O. (2006). Lozh. Tri sposoba vyyavleniya. Kak chitat mysli lzhetsa, kak obmanut detektor lzhi [Lying. Three ways to detect. How to read liars' thoughts, how to deceive the lie detector]. Saint-Petersburg: PraimYevroznak.

26. Kholodnyi, Yu.I. (2013). O "edinom nauchnometodicheskom podhode" $\mathrm{k}$ primeneniyu poligrafa [About "a unified scientific methodological approach" to the polygraph use]. Yuridicheskaya psikhologiya - Legal Psychology, 1, 11-13 [in Russian].

27. Chebykin O.Ya. \& Pavlova, I.G. (2009). Stanovlennia emotsiynoyi zrilosti osobystosti: monohrafiia [Development of emotional maturity of personality: a monograph]. Odesa: SVD Cherkasov [in Ukrainian].

28. Shcherbatyh, Yu.V. (2002). Iskusstvo obmana: populiarnaya entsiklopediya [The art of deception: a popular encyclopedia]. Moscow: Izd-vo "Eksmo-Press" [in Russian].

29. Ekman, P. (1999) Psikhologiya lzhi [Telling Lies: Clues to Deceit in the Marketplace, Politics, and Marriage]. Saint-Petersburg: Piter [in Russian].

30. Ekman, P. (2010). Psikhologiya emotsiy [Emotions Revealed: Recognizing Faces and Feelings to Improve Communication and Emotional Life]. SaintPetersburg: Piter [in Russian].

31. Bella M. DePaulo. Deborah A. Kashy, Susan E. Kirkendol, Melissa M. Wyer. \& Jennifer A. Epstein. (1998). Lying in Everyday Life. Journal of Personality and Social Psychology, 70(5), 991-993 [in English].
32. Bok, S. (1978). Lying: Moral choice in public and private life. Sussex [in English].

33. Borland, G.H.\& Raskin D.C. (1973). Detection of deception. Electrodernial activity in psychological research, 419-477. N.Y.: Acad. Press [in English].

34. Carson Th. L., Wokutch R.E. \& Cox J.E. (1989). An ethical analysis of deception in advertizing. Contemporary moral controversies in business, 384-394. N.Y. [in English].

35. Ekman, P. \& Frank, M.G. Lies That Fail. In Lewis, M. \& Saarni, C. (Eds.) (1993). Lying and deception in everyday life, 184-200. New York: Guilford Press [in English].

36. Goleman, D. (2000). Working with Emotional Intelligence. London: Bloomsburry Paperbacks [in English].

37. Hopper, R., \& Bell, R.A. (1984). Broadening the Deception Construct. Quarterly Journal of Speech, 70(3), 288-302 [in English].

38. Koenigs, M. \& Tranel, D. (2007). Irrational Economic Decision - Making after Ventromedial Prefrontal Damage: Evidence from the Ultimatum Game. The Journal of Neuroscience, 27(4), 951-956 [in English].

39. Leeper, R.W. (1965). Some needed developments in the motivational theory of emotions. In: Nebraska symposium on motivation, 13, 26, 34-40, 44-46, 51-57, 65-66 [in English].

40. Levenson, R.W., Ekman, P., Heider, K., \& Friesin, W.V. (1992). Emotion and automic nervous system activity in an Indonesian culture. Journal of personality and social psychology, 62, 927-988 [in English].

41. Lindskold, S., Walters, P.S., \& Koutsourais, H. (1983). Cooperators, Competitors, and Response to GRTT. Journal of Conflict Resolution 27, 3, 521-532 [in English].

42. Lykken, D. (1974). Psychology and the lie detection industry. American Psychologist, 29, 725-739 [in English].

43. National Research Council The Polygraph and Lie Detection (2002). Washington, DC: The National Academies Press [in English].

44. Nelson, R. (2015). Scientific Basis for Polygraph Testing. Polygraph, 44(1), 28-61 [in English].

45. Von Eckhartshausen, Karl (2005). The Absolute Truth Lying the in the Center of the Mystery. Kessinger Publishing [in English].

46. Vrij, A., Akehurst, L. \& Morris, P. (1997). Individual differences in hand movements during deception. Journal of Nonverbal Behavior, 21, 87-102.

47. Vrij A., Granhag P.A., Verschuere B. (2015).

Detecting Deception: Current Challenges and Cognitive Approaches. John Wiley \& Sons [in English].

48. Wilson, G. (2016). Body Language: The Signals You Don't Know You're Sending, and How to Master Them. United Kingdom: Icon Books Ltd [in English]. 


\section{ЛІТЕРАТУРА}

1. Алексеев Л. Психофизиология детекции лжи: Методология. / Л. Г. Алексеев. - М.: ООО «Галлеяпринт», 2011. - $108 \mathrm{c.}$

2. Баришполець О. Т. Брехня в інформаційному просторі та міжособовій комунікації: монографія / О. Т. Баришполець; Національна академія педагогічних наук України, Інститут соціальної та політичної психології. - Кіровоград: Імекс-ЛТД, 2013. - 648 с.

3. Варламов В. А. Детектор лжи / В. А. Варламов. - Краснодар, 2004. - 230 с.

4. Вихман А. А. Некоторые особенности индивидуальности лжецов юношеского возраста / А. А. Вихман // Сиб. пед. журн. - 2010. - № 11 .

5. Гельгорн Э., Луфборроу Дж. Эмоции и эмоциональные расстройства. Нейрофизиологическое исследование / Э. Гельгорн, Дж. Луфборроу / перевод с английского О.С. Виноградовой, под редакцией и с предисловием действ. члена АМН П.К. Анохина. М.: Мир, 1966. - 673 с.

6. Дубровский Д. И. Обман. Философскопсихологический анализ, 2-е доп. издание / Д. И. Дубровский. - М.: Канон + РООИ «Реабилитация», 2010. $-336 \mathrm{c}$.

7. Жданова О. О. Психологические особенности понимания лжи Текст / О. О. Жданова // Вестник Российского гуманитарного научного фонда. - М., 1998. - № 4. - С. 183-189.

8. Журин С. И., Алюшин М. В. Обзор современных полиграфов / С. И. Журин, М. В. Алюшин. Мир и безопасность. - 2003. - №2.

9. Знаков В. В. Западные и русские традиции в понимании лжи: размышления русского психолога над исследованиями Пола Екмана / В. В. Знаков. СПб: Питер, 1999. - 272 с. - (Серия «Мастера психологии»).

10. Изард К. Е. Психология эмоций / К. Е. Изард. - СПб: Питер, 2000. - 454 с.

11. Ильин Е. П. Психология общения и межличностных отношений / Е. П. Ильин. - СПб: Питер, 2013. $-576 \mathrm{c}$.

12. Князев В., Варламов Г. Полиграф и его практическое применение: учеб. пособие / В. Князев, Г. Варламов. - М.: «Принт-Центр», 2012. - 859 с.

13. Кочарян О. С. Емоційна зрілість особистості: дослідження феномену / О. С. Кочарян, М. А. Півень // Науковий вісник Миколаївського державного університету імені В.О. Сухомлинського: збірник наукових праць / за ред. С.Д. Максименка, Н.О. Євдокимової. Т. 2. - Вип. 9. - Миколаїв: МНУ імені В. О. Сухомлинського, 2012. - С. 140-144.

14. Лесли И. Прирожденные лжецы. Мы не можем жить без обмана; пер. с англ. / И. Лесли. - М.: Рипол Классик, 2012. - 351 с.

15. Лурия А. Р. Природа человеческих конфликтов: Объективное изучение дезорганизации поведения человека / Лурия А. Р. / Под общей ред.
В.И. Белопольского. - М.: «Когито-Центр», 2002. $527 \mathrm{c}$.

16. Максименко С. Д. Психологія особистості: підручник / С. Д. Максименко, К. С. Максименко, М. В. Папуча. - К.: ТОВ «КММ», 2007. - 296 с.

17. Мотлях О. I. Поліграф: наукова природа походження, нормативно-правове регулювання та допустимі межі застосування: монографія / О. І. Мотлях. К.: Освіта України, 2012. - 394 с.

18. Никитина Е. В. Ложь и обман: проблема понятийного разграничения / Е. В. Никитина // Психологическое обеспечение национальных проектов развития общества: опыт, инновационные технологии, ментальные барьеры: материалы международного конгресса. - М.; Кострома: КГУ им. Н.А. Некрасова, 2008. - C. $275-277$.

19. Никитина Е. В. Теоретические аспекты феномена лжи / Е. В. Никитина // Социальная психология XXI столетия / Под. ред. В.В. Козлова. - Ярославль, 2002. - С. 274-276.

20. Орлов Ю. К., Холодный Ю. И. Судебнопсихофизиологическая экспертиза с применением полиграфа: проблема допустимости / Ю. К. Орлов, Ю. И. Холодный // Вестник Академии экономической безопасности МВД России. - 2009. - № 12. - С. 83-88.

21. Павлов И. П. Рефлекс свободы / И. П. Павлов. - СПб: Питер, 2001. - 424 с.

22. Пеленицын А. Б. Так что же все-таки определяет полиграф? / А. Б. Пеленицын, А. П. Сошников, О. В. Жбанкова // Вестник криминалистики. - М., 2011. - Вып. 2 (3). - С. 7-18.

23. Поповичев С. В. Легко солгать тяжело. Инструментальная детекция лжи: от идеологии к технологии / С. В. Поповичев. - М., 2011. - 400 с.

24. Симонов П. В. Эмоциональный мозг / П. В. Симонов. - М.: Наука, 1981. - С. 20.

25. Фрай О. Ложь. Три способа выявления. Как читать мысли лжеца, как обмануть детектор лжи / О. Фрай. - СПб: Прайм-Еврознак, 2006. - 284 с.

26. Холодный Ю. И. О «едином научнометодическом подходе» к применению полиграфа / Ю. И. Холодный // Юридическая психология. - М.: Юрист, 2013. - № 1. - С. 11-13.

27. Чебикін О. Я. Становлення емоційної зрілості особистості: монографія / О. Я. Чебикін, І. Г. Павлова. - Одеса: СВД Черкасов, 2009. - 230 с.

28. Щербатых Ю. В. Искусство обмана: популярная энциклопедия / Ю. В. Щербатых. - Издательство «Эксмо-Пресс», 2002. - 720 с.

29. Экман П. Психология лжи [Telling Lies: Clues to Deceit in the Marketplace, Politics, and Marriage] / П. Экман. - СПб: Питер, 1999 (2000, 2003, 2008, 2009, 2010). $-270 \mathrm{c.}$

30. Экман П. Психология эмоций [Emotions Revealed: Recognizing Faces and Feelings to Improve Communication and Emotional Life] / П. Экман / пер. с англ. В. Кузин. - СПб: Питер, 2010. - 336 с. 
31. Bella M. DePaulo. Lying in Everyday Life / Bella M. DePaulo. Deborah A. Kashy, Susan E. Kirkendol, Melissa M. Wyer. and Jennifer A. Epstein. // Journal of Personality and Social Psychology. - 70(5). 1998. - P. 991-993.

32. Bok S. Lying: Moral choice in public and private life / S. Bok. - Sussex. - 1978. - 326 p.

33. Borland G.H., Raskin D.C. Detection of deception / G. H. Borland, D. C. Raskin // Electrodernial activity in psychological research. - N.Y.: Acad. Press, 1973. - P. 419-477.

34. Carson Th. L., Wokutch R.E., Cox J.E. An ethical analysis of deception in advertizing / Th. L. Carson, R. E. Wokutch, J. E. Cox // Contemporary moral controversies in business. - N.Y. - 1989. - P. 384394.

35. Ekman, P. \& Frank, M.G. Lies That Fail / P. Ekman. \& M. G. Frank // In Lewis, M. \& Saarni, C. (Eds.) Lying and deception in everyday life. - New York: Guilford Press, 1993. - P. 184-200.

36. Goleman D. Working with Emotional Intelligence / D. Goleman. - London: Bloomsburry Paperbacks, 2000. - 394 p.

37. Hopper R., \& Bell R. A. Broadening the Deception Construct / Hopper R., \& Bell R. A. // Quarterly Journal of Speech. - 70(3). - 1984 - P. 288302.

38. Koenigs M., Tranel D. Irrational Economic Decision - Making after Ventromedial Prefrontal Damage: Evidence from the Ultimatum Game / M. Koenigs, D. Tranel // The Journal of Neuroscience. January 24. - 27(4). - 2007. - P. 951-956.

39. Leeper R. W. Some needed developments in the motivational theory of emotions / R. W. Leeper // In: Nebraska symposium on motivation. - vol. 13. - Lincoln. - 1965. - pp. 26, 34-40, 44-46, 51-57, 65-66.
40. Levenson R. W. Emotion and automic nervous system activity in an Indonesian culture / R. W. Levenson, P. Ekman, K. Heider, \& W. V. Friesin // Journal of personality and social psychology. - 62. 1992. - P. 927-988.

41. Lindskold S., Walters P. S., \& Koutsourais H. Cooperators, Competitors, and Response to GRTT / S. Lindskold, P. S. Walters, \& H. Koutsourais // Journal of Conflict Resolution. - 27. - no. 3. - September 1983. - P. 521-532.

42. Lykken D. Psychology and the lie detection industry / D. Lykken // Amer. Psychologist. - 1974. - V. 29. - P. 725-739.

43. National Research Council The Polygraph and Lie Detection. - Washington, DC: The National Academies Press, 2002.

44. Raymond Nelson. Scientific Basis for Polygraph Testing / Nelson Raymond // Polygraph. - 44(1). - 2015. - P. 28-61.

45. Von Eckhartshausen, Karl The Absolute Truth Lying the in the Center of the Mystery / Karl Von Eckhartshausen. - Kessinger Publishing, 2005. - 48 p.

46. Vrij A., Akehurst L. \& Morris P. Individual differences in hand movements during deception / A. Vrij, L. Akehurst \& P. Morris // Journal of Nonverbal Behavior, 21, 1997. - P. 87-102.

47. Vrij A., Granhag P. A., Verschuere B. Detecting Deception: Current Challenges and Cognitive Approaches / A. Vrij, P. A. Granhag, B. Verschuere. - John Wiley \& Sons, 2015. $-368 \mathrm{p}$.

48. Wilson G. Body Language: The Signals You Don't Know You're Sending, and How to Master Them / G. Wilson. - United Kingdom: Icon Books Ltd, 2016. 240 pages.

Олексій Якович Чебикін,
доктор психологічних наук, професор, завідувач кафедри теорії та методики практичної психології, Олена Юрї̈на Косьянова, кандидат психологічних наук, викладач кафедри теорії та методики практичної психології, Південноукраӥнський національний педагогічний університет імені К. Д. Уиинського, вул. Старопортофранківська, 26, м. Одеса, Украӥна

\section{СХИЛЬНІСТЬ ДО ОБМАНУ ЗА ПОКАЗНИКАМИ МЕТОДИКИ ЕМОЦИЙНОЇ ЗРІЛОСТІ ТА ПОЛІГРАФНОГО ОБСТЕЖЕННЯ}

У дослідженні було виділено три етапи у становленні поліграфного методу: етап пошуку ознак, які можуть характеризувати схильність особистості до обману; етап побудови окремих методик, орієнтованих на виявлення обману; етап створення та впровадження комплексної апаратної поліграфної методики. Побудовано теоретичну модель структури поліграфного дослідження, яка складається з трьох груп категорій і понять, що використовуються при організації, проведенні, отриманні результатів та інтерпретації даних: фізіологічних, що характеризують закономірності перебігу даних процесів; психологічних, що відображають істотні властивості та відносини; інструментально-технічних, що відображають специфіку поліграфного методу. На основі узагальнення існуючих підходів виділено «когнітивні теорії поліграфа» і «емоційно-вольові теорії поліграфа», які можуть використовуватися при інтерпретації отриманих даних. Побудовано поліграфний опитувальник діагностики схильності до обману, який дозволяє виділити і проаналізувати показники, що характеризують схильність до прихованого обману, вербального і загального обману. Аналіз первинних даних дозволив згрупувати обстежених випробовуваних за: статевою ознакою (чоловіки, жінки); напрямами підготовки фахівців (психологія, 
історія, фізика, судноводіння, образотворче мистецтво); ступенем вираженості схильності до обману (високий, середній, низький); типом емоційної зрілості (емпатійний, саморегуляціонний, експресивний, експресивноемпатійний). На основі даних кореляційного аналізу загальної вибірки встановлено, що найбільшою кількістю зв'язків володіє інтегративний показник схильності до обману, який досить тісно пов'язаний з показниками, що визначають емоційну зрілість, і ії компонентами - емоційною експресивністю, емоційною саморегуляцією i емпатією. Проведено міжгруповий факторний аналіз у групах із різним рівнем схильності до загального обману, який показав, що в залежності від його прояву відбуваються зміни в домінуванні того чи іншого компонента емоційної зрілості. Поглиблений аналіз показав, що в структурі емпатійного типу отримано високі взаємозв'язки між показниками схильності до обману й емоційної зрілості, що може вказувати на вірогідну оцінку схильності даного типу до обману. В цілому отримані результати підтверджують гіпотезу про те, що схильність до обману особистості може визначатися ознаками емоційної зрілості, основною з яких, згідно з отриманими результатами, виступає емпатійна складова.

Ключові слова: поліграфне дослідження, типи емоційної зрілості, схильність до обману, діагностика схильності особистості до обману з урахуванням даних емоційної зрілості.

Submitted on 22.05.2017 